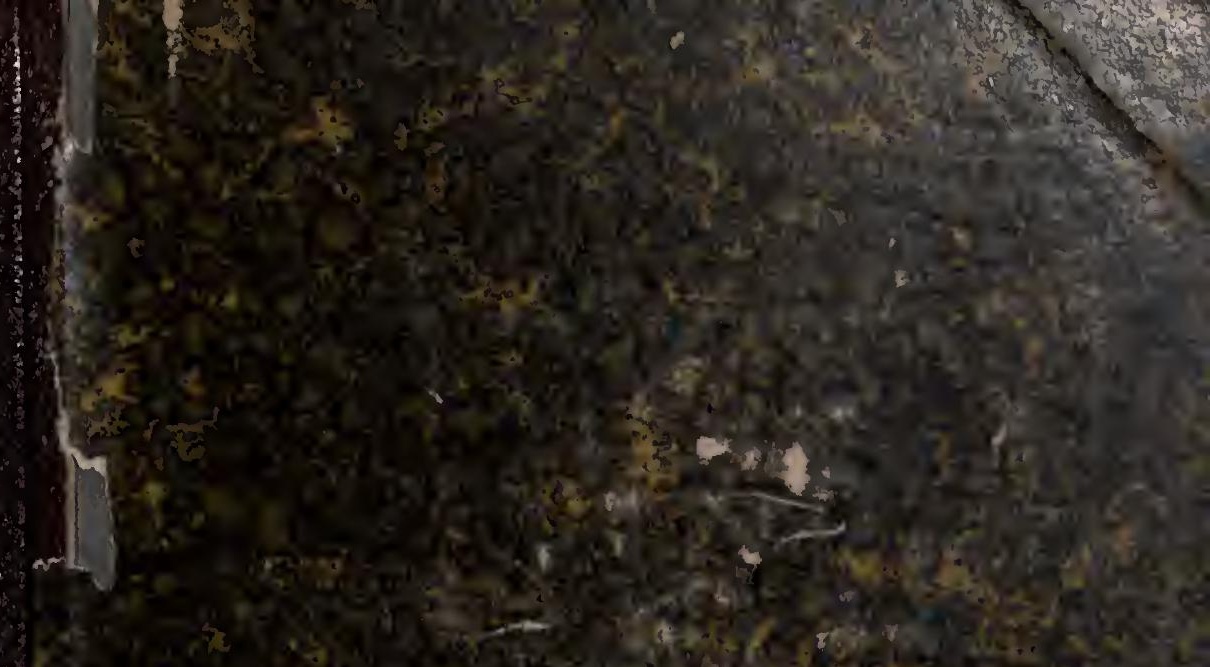

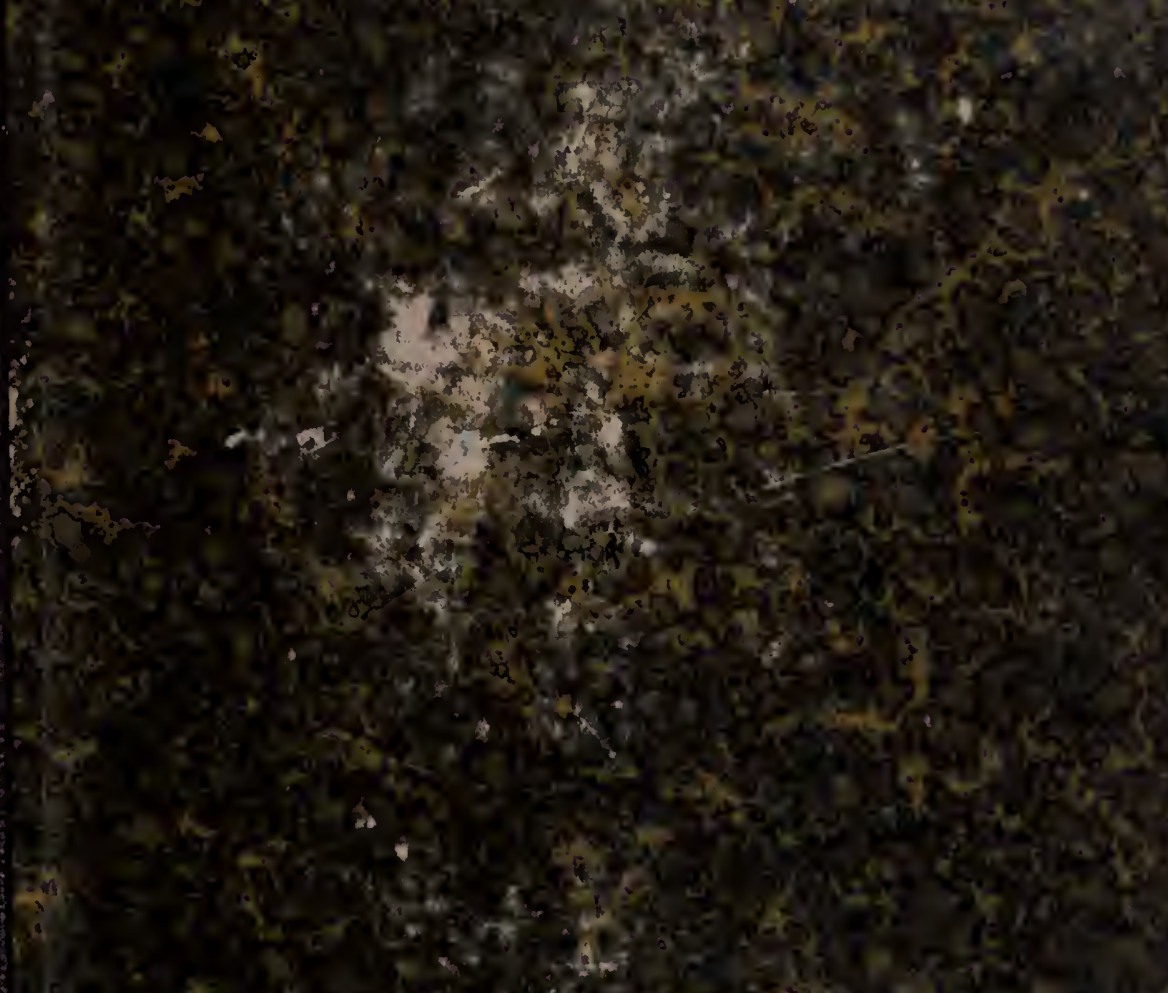

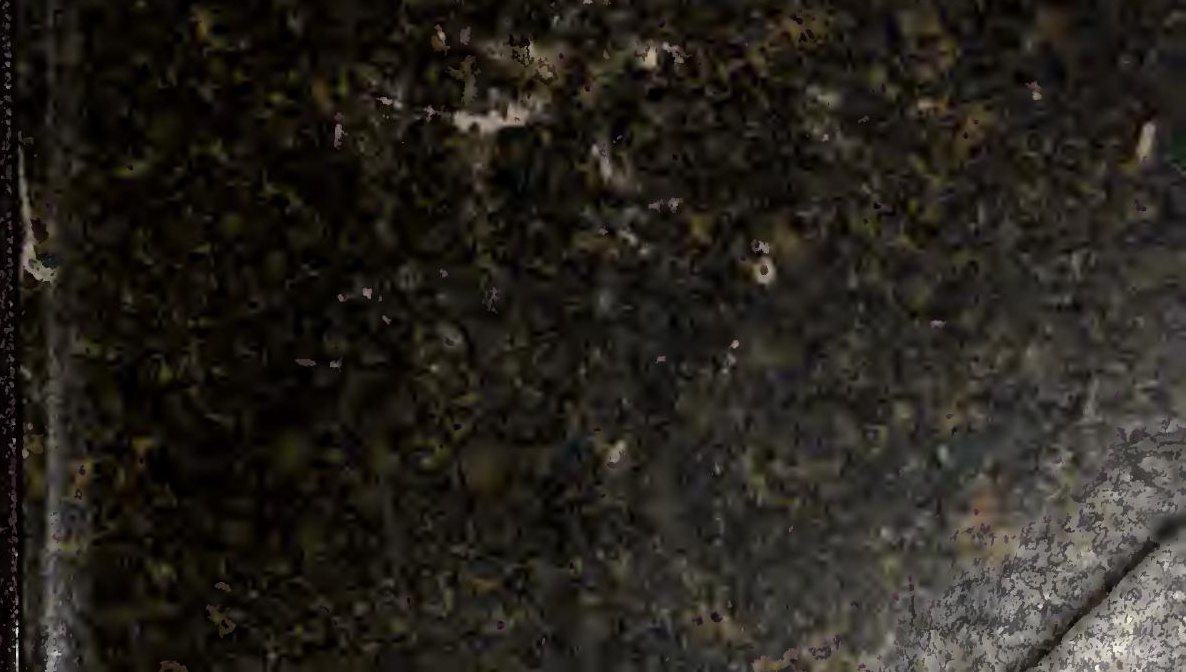



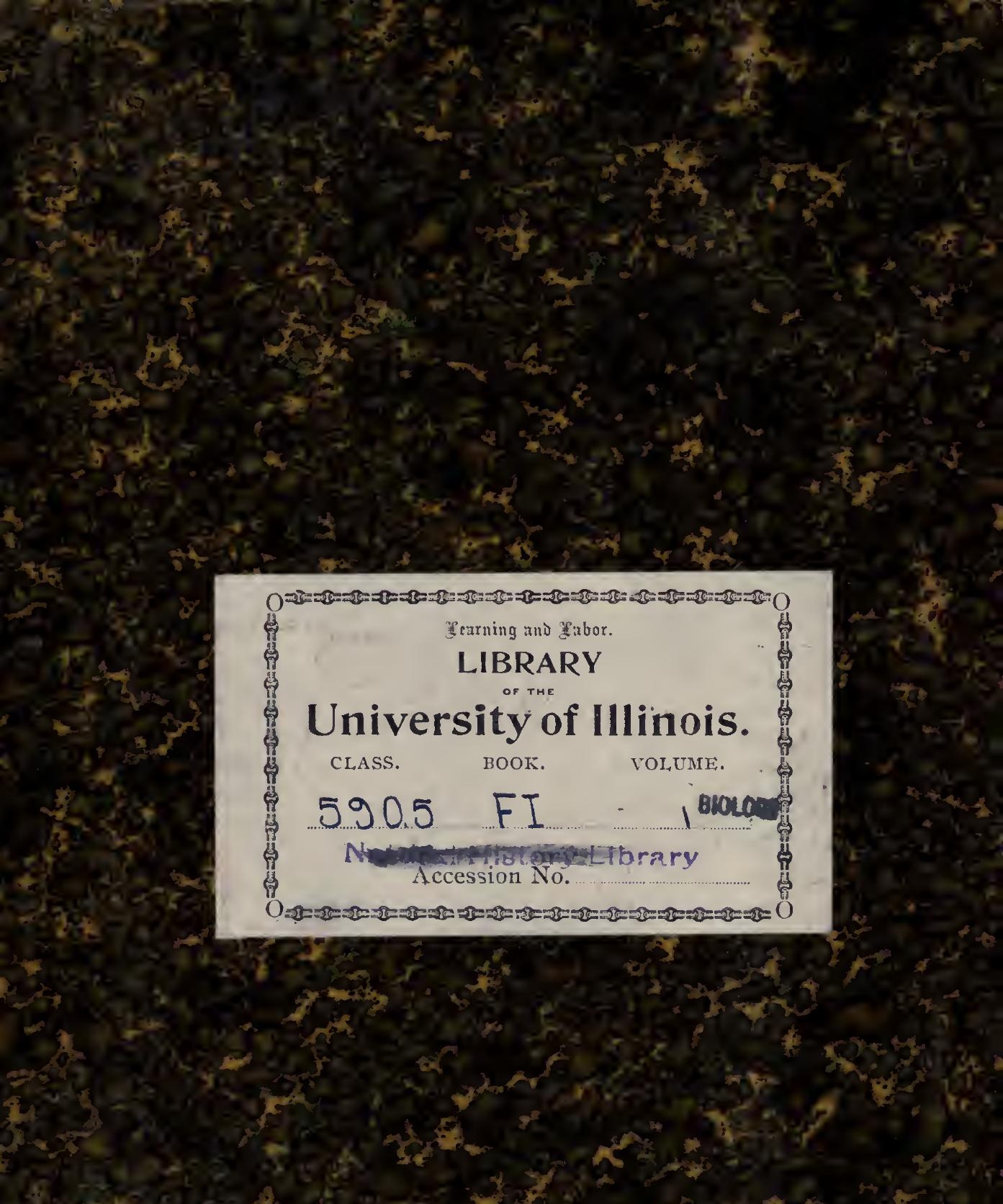

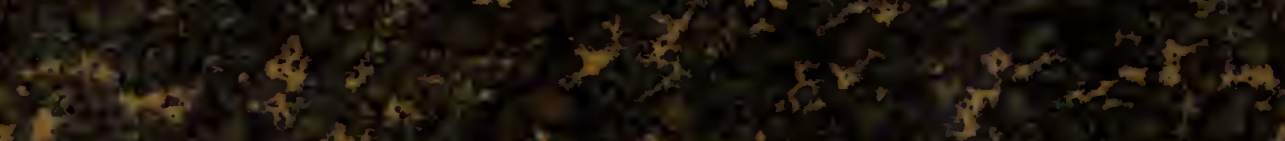

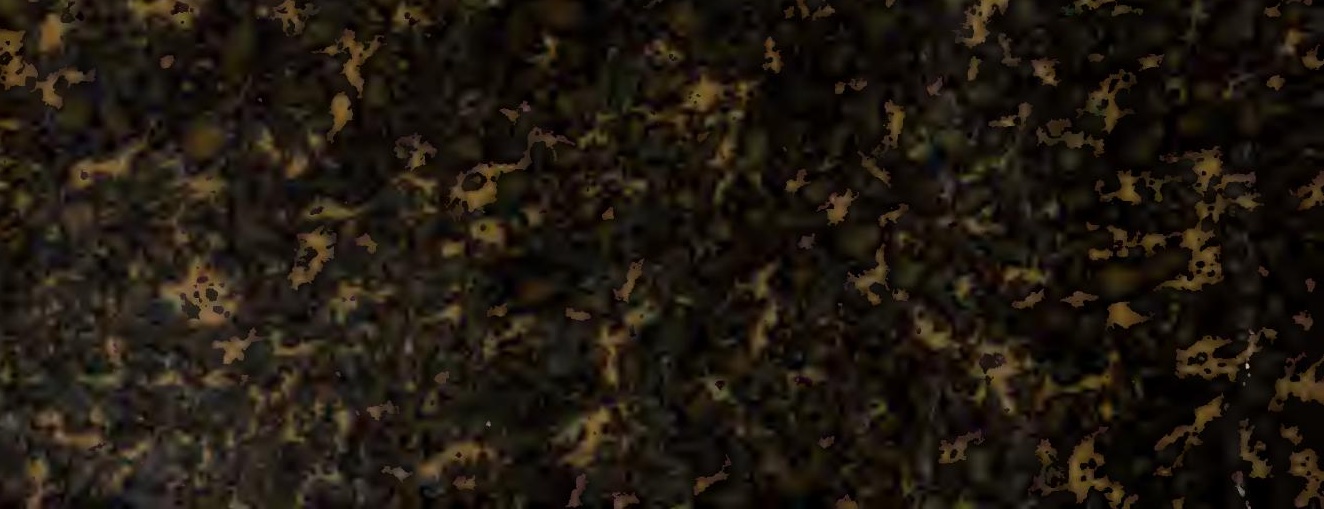





Field Columbian Museum

Publication $4 \mathrm{r}$.

Zoological Series.

VoL. I, No. 17.

\section{NOTES ON A COLLECTION}

\section{OF FISHES AND AMPHIBIANS}

FROM

\section{MUSKOKA AND GULL LAKES.}

BY

S. E. MeEK,

Assistant Curator, Department of Zoology.

D. G. Elliot, F.R.S.E.,

Curator, Department of Zoology.

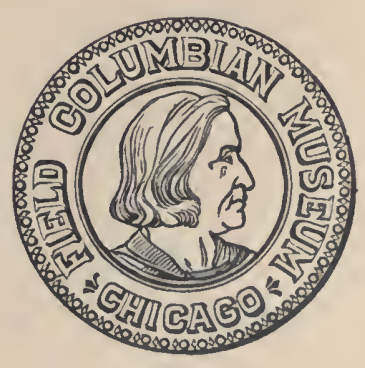

Chicago, U. S. A. November, 1899. 



\title{
NOTES ON A COLLECTION OF FISHES AND AMPHIBIANS FROM MUSKOKA AND GULL LAKES.
}

\author{
BY S. E. MEEK.
}

The present paper is based on a collection of fishes and amphibians made at Gravenhurst, Ontario, by the writer the second week in September, I899. The country about Gravenhurst is very rough and rocky, and contains a large number of lakes. Muskoka, the largest of these, is joined on the north by Rosseau and Joseph Lakes. These three form a body of water about forty-five miles in length, and from a few rods, to more than five miles in width. Its coast line is rough and rocky, excepting that here and there are narrow bays, which usually terminate in sandy beaches or low marshy shores.

-Gull Lake is much smaller than Muskoka, and lies about one and one-half miles east of its southern end. It is about sixty feet higher than Muskoka, into which it drains. Our collection was made in Gull Lake, its outlet, and the southern end of Muskoka Lake.

Commercial fishing is not permitted in these lakes, and the larger game fishes are reported as abundant. During my visit the disagreeable weather prevented fishing for the larger species, and my attention was given mostly to collecting the smaller.

\section{PISCES.}

I. Ameiurus nebulosus (Le Sueur).

(Dog-fish ; Cat-fish.)

Abundant in Gull and Muskoka Lakes. It is sometimes spoken of as Cat-fish or Bullhead, but more often called Dog-fish.

2. Catostomus commersonii (Lacepede).

\section{(Sucker.)}

Abundant in the outlet of Gull Lake. I was informed that many were speared in the spring at the lower part of Gull Lake, and in the upper part of its outlet. 
3. Semotilus atromaculatus (Mitchill).

(Chub.)

Abundant in the outlet of Gull Lake.

4. Abramis chrysoleucas (Mitchill).

One specimen taken in the outlet of Gull Lake. Length, I.86 inches; anal rays, I3.

5. Notropis muskoka, sp. nov.

Length of type 2.9I inches. No. 2964 .

Head, 4 ; depth, 51/2; D., 8; A., 8; scales, 36 (I o from dorsal to ventral fin); teeth, 4-4, tips slightly hooked, grinding surface narrow; eye, $3 \frac{T}{4}$ in the length of the head; snout, $33 / 4$. Body rather terete and slender; snout bluntish; mouth small and slightly oblique; lower jaw the shorter, slightly included; posterior end of maxillary scarcely reaching vertical from the front of orbit. Eighteen scales between nape and dorsal fin, the scales in this region being smaller and more crowded than on sides and posterior dorsal region, much resembling Pimephales notatus in this respect. Origin of the first ray of dorsal fin mid. way between the base of the caudal fin and the tip of the snout. Lateral line incomplete, not extending beyond the fourth scale on each side. The longest (anterior) dorsal rays are nearly three times the length of the posterior ones, the tips of the former extending considerably beyond the tips of the latter when the fin is deflexed; longest dorsal ray, $I 1 / 3$ in head; pectorals, $I 1 / 2$ in head, their tips reaching $2 / 3$ distance from their base to base of ventrals; ventrals 2 in head, their tips reaching to base of anal.

Color olivaceous, darker above, very pale below; a dark band about $2 / 3$ diameter of eye around snout and on sides to base of caudal fin; on the snout this band is confined to the upper jaw; between this band and the darker color on the dorsal region is a lighter band of about the same width; a dark vertebral line present, also a similar one from base of anal to caudal fin.

Twenty-four specimens varying in length from $\mathrm{I} \cdot 3 \mathrm{I}$ inches to 2.83 inches, taken from the lower part of Gull Lake, and from the outlet just below the first falls. The lateral line on most of the specimens is as described in the type specimen. In a few of the other specimens it is absent on the first scales and appears at intervals along the sides on about I 2 scales, occasionally, usually in the smaller specimens, it is absent altogether. It is less developed in this species than in any other of the genus. 
This species differs from Notropis cayuga, Meek, in the reduced size of the scales before dorsal fin, the more slender body, less blunt snout, and the slightly larger and more oblique mouth, and the more incomplete lateral line. It is also a larger fish than Notropis cayuga.

6. Notropis cornutus (Mitchill).

(Silverside; Shiner.)

Abundant.

7. Cristivomer namycush (Walbaum).

(Lake trout; Salmon trout.)

Caught in large numbers in Muskoka Lake; not found in Gull Lake.

8. Salvelinus fontinalis (Mitchill).

(Brook trout ; speckled trout.)

Reported as common in streams and many smaller lakes, none taken in Gull Lake.

A white fish and a lake herring are said to be found in Muskoka Lake, none were taken during my visit and I am unable to give name of the species.

9. Umbra limi (Kirtland).

Abundant in lower part of Gull Lake and in its outlet.

ı. Lucius lucius (Linnæus).

(Pike. Pickerel.)

This species is not found in Gull Lake. Large numbers are caught each year in Muskoka Lake.

II. Lucius masquinongy (Mitchill).

(Muscalonge.)

I saw none of this species. It is reported as less common in Muskoka Lake than the preceding; not found in Gull Lake.

12. Eupomotis gibbosus (Linnæus).

(Sunfish.)

In Gull and Muskoka Lakes, apparently common.

The specimens collected are more slender (depth $21 / 3$ to $2 \mathrm{~T} / 2$ ) than specimens from northern Illinois. In the young the sides have from 12 to $r_{4}$ dark bars. These bars are quite conspicuous in specimens 5 inches in length. 
13. Micropterus dolomieu Lecepede.

(Bass. Green Bass; Small Mouthed Black Bass.)

So far as I could learn this is the most abundant game fish in Gull and Muskoka Lakes. The day I arrived one gentleman and his wife brought in $4^{6}$ specimens from Muskoka Lake, the result of less than a half day's catch.

I4. Micropterus salmoides (Lacepede).

(Large Mouthed Black Bass.)

Mr. Currie, of Bala, reports this species from Muskoka Lake. None were seen by me.

I5. Stizostedion vitreum (Mitchill).

(Pickerel. Wall Eyed Pike; Pike.)

Mr. Cockburn, manager of the Muskoka Navigation Company, reports this species as very abundant in Muskoka Lake, none were taken during my visit.

It is difficult to always understand the use of the names Pike and Pickerel. On the Muskoka Lakes the name Pickerel is usually employed for this species, while Lucius lucius is more commonly known as the Pike. According to Mr. Currie, Lucius lucius is not found in Muskoka Lake, but in its outlet.

16. Perca flavescens (Mitchill).

(Perch.)

Abundant in Gull and Muskoka Lakes.

I7. Etheostoma boreale Jordan.

Five specimens, largest 2. Io inches in length, smallest 1.42 inches. All were taken in the lower end of Gull Lake. Dorsal ix-Io; anal ii, 6 or 7, scales 52; lateral line developed on anterior half of body. Cheeks with a few scales; breast naked. Soft dorsal, caudal and pectoral fins with dark bars and a brownish red tinge, other fins white; a brownish red tinge on sides, most conspicuous between the darker markings; ro or I I black bars across the back, those on the sides are more or less broken up and not so evident. This Darter was first noticed by Dr. Jordan in I884. At present it is known only from a small stream near Montreal and from Gull Lake. It probably inhabits the southern portions of the Provinces of Quebec and Ontario. It is found farther north than any other of our eastern darters. 


\section{AMPHIBIA.}

I. Diemyctylus viridescens Rafinesque.

One specimen from lower end of Gull Lake.

2. Hyla pickeringii (Storer).

Common along the outlet of Gull Lake.

3. Rana pipens Gmelin.

(Green frog.)

Abundant.

4. Rana clamata Daudin.

Apparently less common than the preceding.

5. Rana cantabridgensis Baird.

Twenty-one specimens (all I saw) were caught in a comparatively small area near the outlet of Gull Lake; smaller.93 inches in length, largest I.I4 inches in length. Between the dermal folds are many short folds irregularly placed; back with many small warty-like tubercles; sides nearly smooth. Color of back reddish or reddish-brown to a very dark brown, with a darker central area, sides lighter with a few small black spots on some specimens. Under surface white, belly and throat profusely spotted with dark brown. No vertebral stripe or stripe on anterior portion of the thigh on any of the specimens.

Though these specimens were found near the water, none made any special attempt to reach it when pursued; the weather being cool, they were quite inactive and would only make a few short jumps toward some log or hiding-place before we were able to capture them. So far as observed there, the habits of this species were much like that of Hyla pickeringii. The other two species of Rana, when started, would hasten toward the water; these I captured with the use of a 22 cal. revolver, using shot cartridges. 






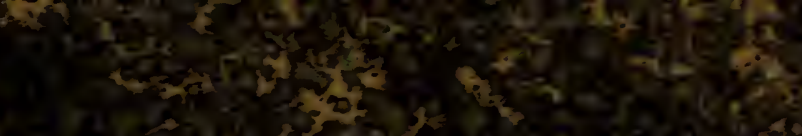

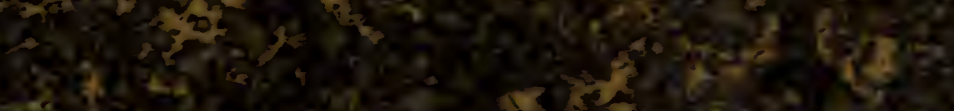

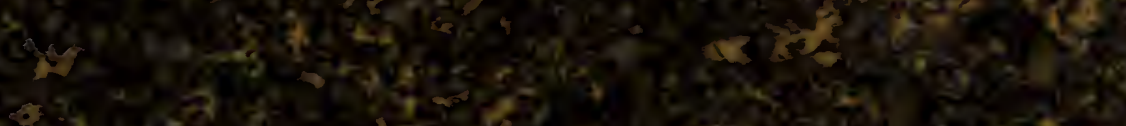

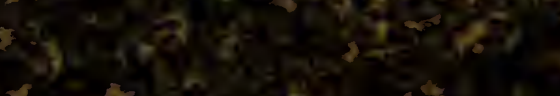
$\cos 20$

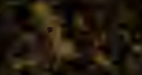

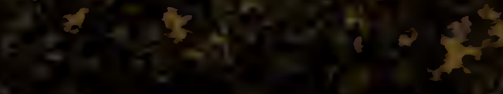

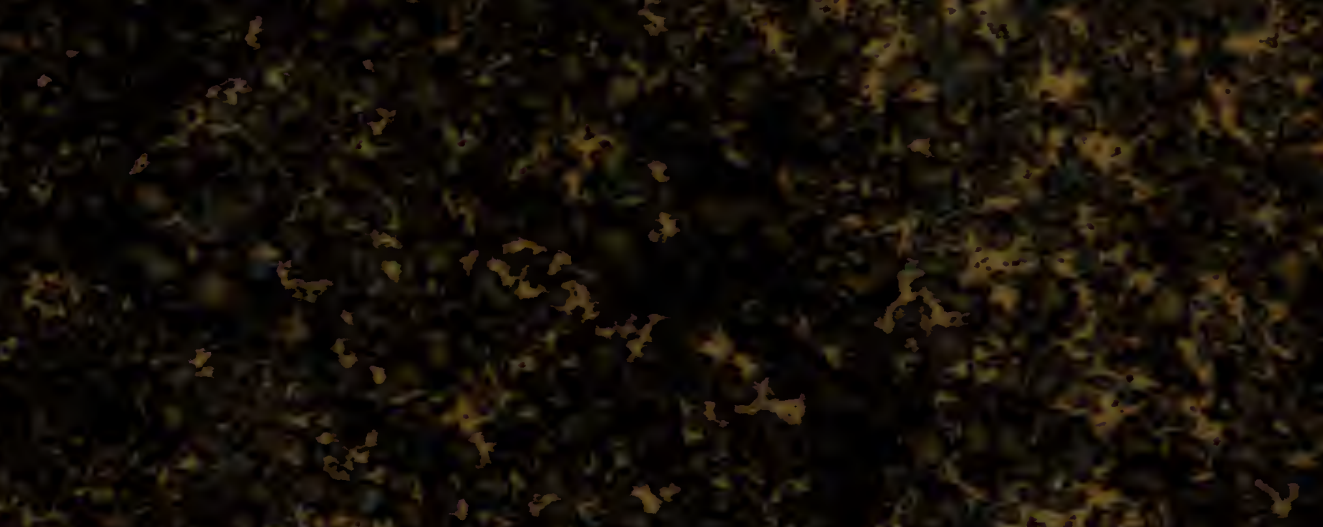

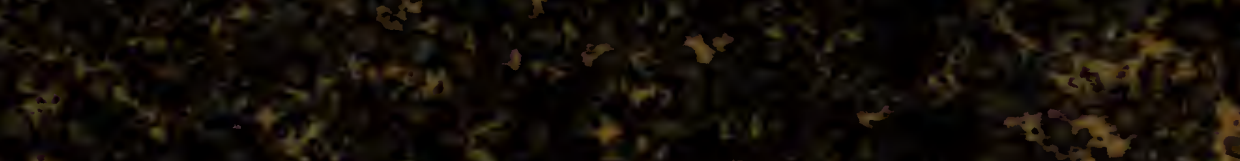

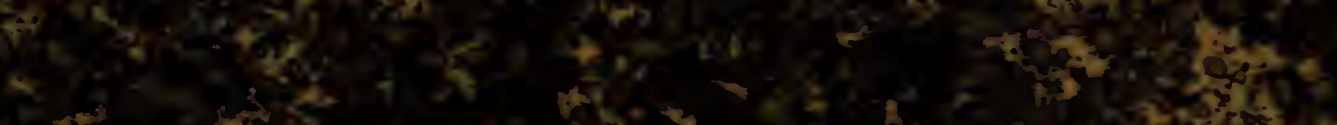

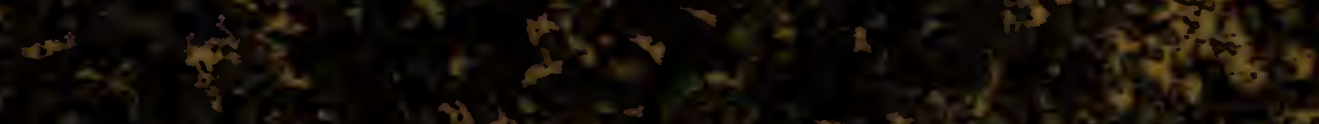

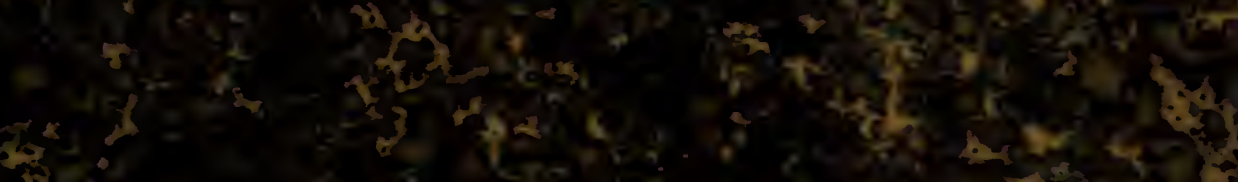
$\cos ^{2} e^{2}=$

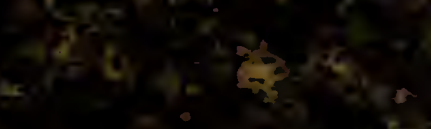

$x^{2}$

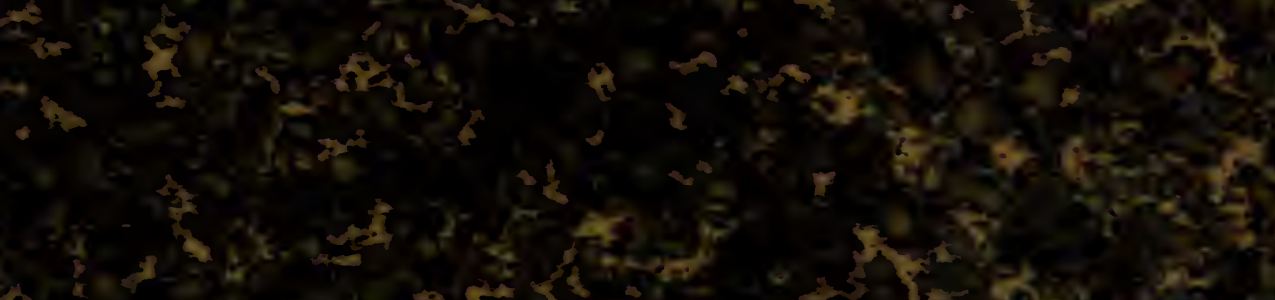

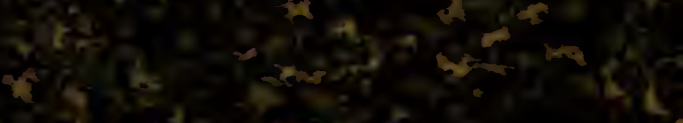

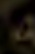

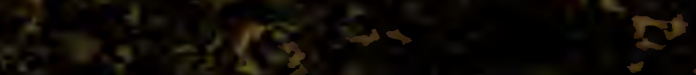

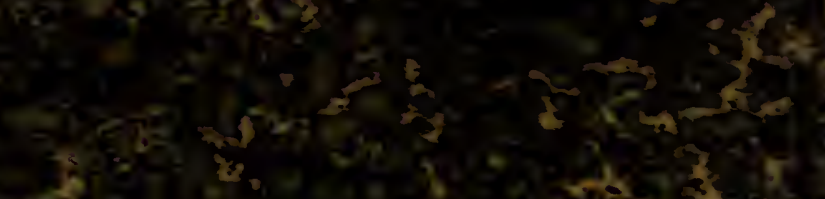

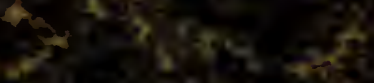
$x_{i=2}$

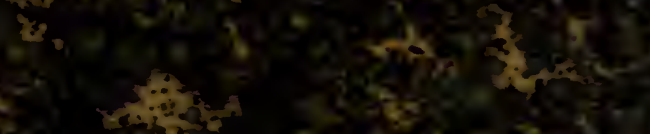

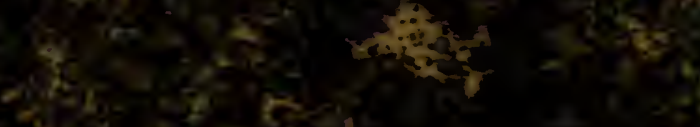
3

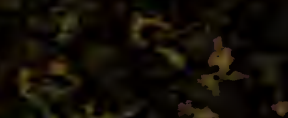
428 as cos

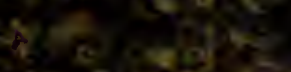

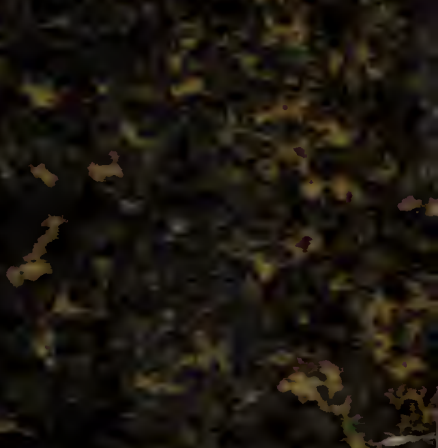


